\title{
A Cryocooled Superconducting Magnet for High Magnetic Field Science
}

\author{
M. Ishizuka, T. Itou, J. Sakuraba, S. Awaji*, G. Nishijima* and K. Watanabe* \\ Research and Development Center, Sumitomo Heavy Industries, Ltd., 19 Natsushima-chou, Yokosuka, Kanagawa, $237-8555$ Japan \\ *Institute for Materials Research, Tohoku University, 2-1-1 Katahira, Aoba-ku, Sendai 980-8577, Japan
}

We have developed a cryocooled superconducting magnet for the $28 \mathrm{~T}$ hybrid magnet. The liquid helium-free hybrid magnet has been designed to generate the magnetic field of $28 \mathrm{~T}$ that can be accomplished by combining $9 \mathrm{~T}$ generation due to the cryocooled superconducting magnet with $19 \mathrm{~T}$ generation due to a water-cooled resistive magnet, which is inserted into a room bore of the superconducting magnet. In this work, we developed the 10 T cryocooled superconducting magnet with the $360 \mathrm{~mm}$ room bore, whose inner coils are wound for employing high-strength $\mathrm{Nb}_{3} \mathrm{Sn}$ wires in consideration of large hoop stress. The liquid helium-free hybrid magnet has reached the generation of $27.5 \mathrm{~T}$, which is greatly useful for high magnetic field science. The hybrid magnet also achieved the high magnetic-force field $(B \cdot d B z / d z)$ of $4500 \mathrm{~T}^{2} / \mathrm{m}$, which could levitate materials of small magnetic susceptibility such as an InSb semiconductor.

Key words: cryocooled superconducting magnet, hybrid magnet, high magnetic field science, high magnetic-force field, high-strength $\mathrm{Nb}_{3} \mathrm{Sn}$ wire

\section{強磁場科学用冷凍機冷却超電導マグネットの開発 \\ 石塚正之・伊藤智幸・櫻庭順二・淡路智* ・西島元 ${ }^{*} \cdot$ 渡辺和雄* \\ 住友重機械工業株式会社，神奈川県横須賀市夏島町 19（广237-8555） \\ *東北大学金属材料研究所, 仙台市青葉区片平 2-1-1（广980-8577）}

\section{1. はじめに}

磁気科学分野の研究において, 強磁場の利用は, それま での弱磁場では応答が小さかったため, 捉えることが困難 であった現象を検出することが可能となる，最近では，小 型冷凍機の性能向上によって, 液体へリウムを用いること なく伝導にて超電導コイルを冷却する超電導マグネット が普及し，10 T 級の磁場であれば比較的容易に利用するこ とが可能となっている ${ }^{1)}$. しかしながら, 磁気科学におけ る物性研究, 新材料創成, プロセス制御, 超電導材料, 半 導体材料, 生物研究, 化学研究等の分野では $20 \mathrm{~T}$ を超え る更なる強磁場が必要とされ, そのため, 各国において定 常強磁場を発生させるハイブリッドマグネット施設が保 有されている.

ハイブリッドマグネットは, 超電導マグネットの内側に 水冷銅マグネットを挿入した組み合わせ構造であり，それ ぞれ単独では発生できない強磁場を定常的に発生させる ことができる. 到達磁場としては, 東北大学金属材料研究 所付属強磁場超伝導材料研究所の $31.1 \mathrm{~T}$, アメリカの国立 高磁場研究所の $45 \mathrm{~T}$, 日本の物質・材料研究機構の $37.3 \mathrm{~T}$, フランスのグルノーブル強磁場研究所の $31.4 \mathrm{~T}$, オランダ のナイメーゲン磁石研究所の $30.4 \mathrm{~T}$ などが挙げられ ${ }^{2)}$ ，こ れら全てのハイブリッドマグネットにおいて, その構成さ れている超電導マグネットは, 液体ヘリウムにより浸漬泠 却されている.

こうした中, 我々は早くから小型冷凍機による伝導冷却 超電導マグネットの開発に着手し, これまでに, 冷凍機冷 却超電導マグネットにおいて, 直径 $52 \mathrm{~mm}$ 貫通室温空間 にコイル中心で $15 \mathrm{~T}$ の磁場を発生させる強磁場タイプの 超電導マグネット ${ }^{3), 4)}$ (以下, $15 \mathrm{~T}-\phi 52 \mathrm{~mm}$ 冷凍機冷却超 電導マグネットと呼ぶ） あるいは直径 $220 \mathrm{~mm}$ の貫通室温
空間にコイル中心で 6 T を発生させる大口径タイプの超電 導マグネット ${ }^{1)}$ (以下， $6 \mathrm{~T}-\phi 220 \mathrm{~mm}$ 冷凍機冷却超電導マ グネットと呼ぶ）を開発してきた.さらに，この冷凍機冷 却超電導マグネットを，ハイブリッドマグネットの液体へ リウム浸漬冷却超電導マグネットと置き換えることを検 討してきた ${ }^{5)}$. ハイブリッドマグネットの超電導マグネッ 卜を冷凍機冷却超電導マグネットに置き換えることで, 煩 わしい液体へリウム注入作業が不要になり，長期連続運転 が可能となる大きなメリットが得られる. 強磁場下での物 性研究, 生物研究, 化学研究等では連続運転が必要となる 実験もあり，今回開発するハイブリッドマグネットの使用 により，今後新たな知見を得ることが期待できる.

本研究においては，磁気科学分野における強磁場源の提 供に焦点を当て，液体へリウム冷媒を必要としない，28 T 強磁場ハイブリッドマグネットを開発することを目的と する. 19 T 水冷銅マグネットは既に現存するため，本研究 では，その水冷銅マグネットと組み合わせるための，冷凍 機冷却による 9 T 強磁場大口径超電導マグネットの開発が 主な目的となる。

\section{2. 冷凍機冷却超電導マグネットの設計}

\section{1 超電導線材設計}

本研究において開発する, 冷凍機冷却超電導マグネット の基本仕様は, 直径 $360 \mathrm{~mm}$ の貫通した室温ボアを有し, 中心で $10 \mathrm{~T}$ の磁場を発生させることである（以下，10 Tф360 mm 冷凍機冷却超電導マグネットと呼ぶ)。19 T 水冷 銅マグネットをその室温ボアに挿入することで, 水冷銅マ グネットと組み合わせたときは $9 \mathrm{~T}$ 発生として, 室温空間

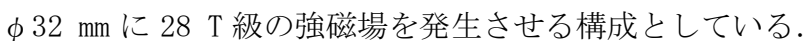
なお，開発する超電導マグネットは，単独で 10 T の磁場 
を発生させる設計とし, 水冷銅マグネットと組み合わせる ときは，10％のマージンを考慮して 9 T までの励磁に留 めることとした.

$10 \mathrm{~T}-\phi 360 \mathrm{~mm}$ 冷凍機冷却超電導マグネットは, 大口径, 強磁場となるため, 超電導コイルには大きなフープ力が加 わることとなる. そのため, コイルを構成する超電導線に ついて, まず, 検討をしなくてはならない. 現在, 商用べ 一スで入手可能な超電導線材としては, $9.8 \mathrm{~K}$ の臨界温度

$\left(T_{\mathrm{c}}\right), 12.5 \mathrm{~T}$ の上部臨界磁場 $\left(B_{\mathrm{c} 2} @ 4.2 \mathrm{~K}\right)$ を示す $\mathrm{NbTi}$ 線, 同じく $18 \mathrm{~K} の T_{\mathrm{c}}, 26 \mathrm{~T}$ の $B_{\mathrm{c} 2}$ を示す $\mathrm{Nb}_{3} \mathrm{Sn}$ 線が挙げら れる. $\mathrm{NbTi}$ 線は $\mathrm{Nb}_{3} \mathrm{Sn}$ 線に比べて低い $T_{\mathrm{c}}, B_{\mathrm{c} 2}$ を示している が，合金であるため，その機械的強度は $0.2 \%$ 耐力で 500 $\mathrm{MPa}$ 以上と高く ${ }^{6)}$, 比較的扱い易い材料である. 一方, $\mathrm{Nb}_{3} \mathrm{Sn}$ 線は, $\mathrm{NbTi}$ 線に比べて高い $T_{\mathrm{c}}, B_{\mathrm{c} 2}$ を示しているが, 金属 間化合物であるため脆く, さらに, その機械的強度は $0.2 \%$ 耐力で $150 \mathrm{MPa}$ と低く, 歪に対する臨界電流 $\left(I_{\mathrm{c}}\right)$ の低下 が大きいため ${ }^{7)}$, 使用する際に注意を要する材料である.

また, $\mathrm{Nb}_{3} \mathrm{Sn}$ 線に関しては, 化合物を生成させるために $650{ }^{\circ} \mathrm{C}$ 前後の高温での熱処理が必要となり, 歪による $I_{\mathrm{c}}$ 低下を避けるため, 通常はコイル形状に巻線した後, 熱処 理を施す製作法（Wind \& React（W \& R）法）にてコイル 化している.このため, コイルが大型化するに伴い, 大き な熱処理炉が必要となり, サイズ制約を受けることとなる. しかしながら, 強磁場を得るためには, 材料物性的に高い $T_{\mathrm{c}}, B_{\mathrm{c} 2}$ を示す $\mathrm{Nb}_{3} \mathrm{Sn}$ コイルの外側に $\mathrm{NbTi}$ コイルを配置させ た複合化したコイルが必要となり, $\mathrm{Nb}_{3} \mathrm{Sn}$ コイルが必要と なってくる. 前章での $15 \mathrm{~T}-\phi 52 \mathrm{~mm}$ 冷凍機冷却超電導マグ ネットでは, この複合化した構成となっている. $15 \mathrm{~T}-\phi$ $52 \mathrm{~mm}$ 冷凍機冷却超電導マグネットの $\mathrm{Nb}_{3} \mathrm{Sn}$ コイルにおい

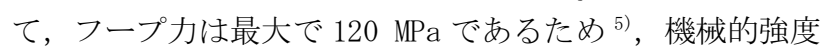
は従来の $\mathrm{Nb}_{3} \mathrm{Sn}$ 線にて十分対応可能であった. しかしなが ら, 強磁場化・大口径化に伴いフープ力が大きくなり, 従 来の $\mathrm{Nb}_{3} \mathrm{Sn}$ 線では機械的強度が不足することが予想され， 高強度化が求められる. 詳細は後述するが, 今回の $\mathrm{Nb}_{3} \mathrm{Sn}$ コイルの概略設計では, $150 \mathrm{MPa}$ を超えるフープ力となる ため, これまでの通常ブロンズ法 $\mathrm{Nb}_{3} \mathrm{Sn}$ 線では対応できな くなる.このため, 線材内部に補強構造を持たせ線材自体 の強度を向上させた $\mathrm{Nb}_{3} \mathrm{Sn}$ 線を使用することとした. 今回 使用する高強度 $\mathrm{Nb}_{3} \mathrm{Sn}$ 線について, 断面構成の概略を従来 のブロンズ法 $\mathrm{Nb}_{3} \mathrm{Sn}$ 線と比較して, Fig. 1 に（a）従来ブロ ンズ法 $\mathrm{Nb}_{3} \mathrm{Sn}$ 線, (b) 高強度 $\mathrm{Nb}_{3} \mathrm{Sn}$ 線として示す. 高強度 $\mathrm{Nb}_{3} \mathrm{Sn}$ 線はFig. 1 の (b) に示されるように, 外側より順に, 安定化銅，外側 $\mathrm{Nb}$ バリア，ブロンズ/ $\mathrm{Nb}_{3} \mathrm{Sn}$, 内側 $\mathrm{Nb}$ バリ ア, CuNi-NbTi 強化材の構成となっている.なお, $\mathrm{CuNi}-\mathrm{NbTi}$ 強化材は, $\mathrm{Cu}-10$ wt. \%Ni マトリックスに NbTi フィラメン 卜を埋め込んだ複合体である。また, 熱処理により各層が 污染されるのを防止するため, ブロンズ/ $\mathrm{Nb}_{3} \mathrm{Sn}$ 層の内側お よび外側に Nb バリアを設けている. Table 1 には, 10 Tф360 mm冷凍機冷却超電導マグネットに使用する線材の 諸元を示す. Table 1 に示すように, $\mathrm{Nb}_{3} \mathrm{Sn}$ 線材及び $\mathrm{NbTi}$

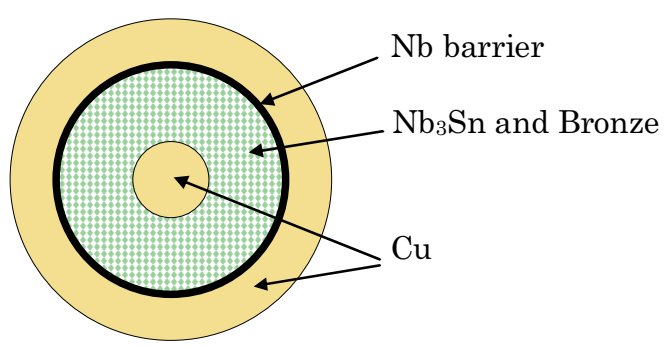

(a) $\mathrm{Cu} / \mathrm{Nb}_{3} \mathrm{Sn}$

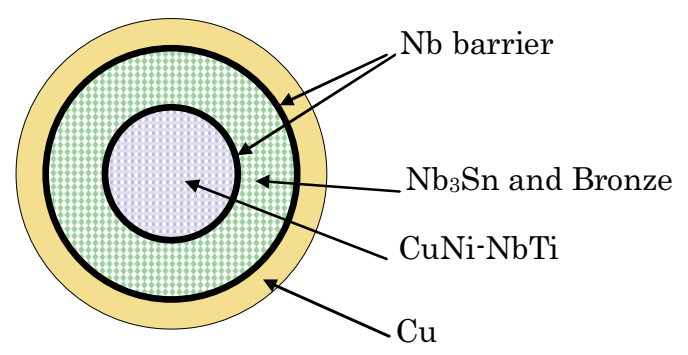

(b) $\mathrm{CuNi}-\mathrm{NbTi} / \mathrm{Nb}_{3} \mathrm{Sn}$

Fig. 1 Schematic figures of the superconducting $\mathrm{Nb}_{3} \mathrm{Sn}$ wire : (a) $\mathrm{Cu} / \mathrm{Nb}_{3} \mathrm{Sn}$ and (b) $\mathrm{CuNi}-\mathrm{NbTi} / \mathrm{Nb}_{3} \mathrm{Sn}$.

線材を用い, それぞれの線材について線径の異なる 2 種類 の線材を用いている. $\mathrm{Nb}_{3} \mathrm{Sn}$ 線については, 2 種類ともに $330 \mathrm{MPa}$ 以上の 0.2 \%耐力を示しており, 通常のブロンズ 法 $\mathrm{Nb}_{3} \mathrm{Sn}$ 線の $150 \mathrm{MPa}$ を大きく上回っている. 今後, さら なる強磁場化・大口径化に対応可能としておくため, 300 $\mathrm{MPa}$ 以上の 0.2 \%而扵をを有することとした。 一方, NbTi 線 については, 従来の線材でも $500 \mathrm{MPa}$ 以上の 0.2 \%耐力を 示し, 今回のコイルでは最大 $155 \mathrm{MPa}$ のフープカであるた め，従来線材を使用することとした。

\section{2 高強度 $\mathrm{Nb}_{3} \mathrm{Sn}$ 線の性能試験}

本研究では, 線材の性能確認のため, 一回り小さいテス トコイルを作製・評価し，使用可能であることを確認して から，実際のコイル製作に移ることとした．テストコイル に使用する線材は, $10 \mathrm{~T}-\phi 360 \mathrm{~mm}$ 冷凍機冷却超電導マグ ネットに使用する線径よりも小さい $\phi 1.0 \mathrm{~mm}$ 線とし, 熱処 理済の線材を巻線する（React \& Wind（R＆W）法）厳し い製作条件でコイル化することとした．10 T凍機冷却超電導マグネットではW\&R 法にてコイルを作製す るが，テストコイルでの R \& W 法の採用は将来のコイル大 型化を想定しているためである.

\section{2. 1 テストコイルの作製}

テストコイルの線材緒元を通常のブロンズ法 $\mathrm{Nb}_{3} \mathrm{Sn}$ 線と 比較して Table 2 に示す. 高強度 $\mathrm{Nb}_{3} \mathrm{Sn}$ 線の 0.2 \%而力は $340 \mathrm{MPa}$ であり, 通常のブロンズ法 $\mathrm{Nb}_{3} \mathrm{Sn}$ 線の約 2.3 倍を 示し，実機に使用する $\phi 1.85 \mathrm{~mm}$ および $\phi 1.80 \mathrm{~mm}$ の高強 度 $\mathrm{Nb}_{3} \mathrm{Sn}$ 線とほぼ同等である。一方， $I_{\mathrm{c}}$ については $12 \mathrm{~T}$ 中 で 209 A であり，通常のブロンズ法 $\mathrm{Nb}_{3} \mathrm{Sn}$ 線の $222 \mathrm{~A}$ とほ ぼ同等となっている，得られた熱処理済の高強度 $\mathrm{Nb}_{3} \mathrm{Sn}$ 線 
Table 1 Major specifications of superconducting wires for $10 \mathrm{~T}^{-} \phi 360 \mathrm{~mm}$ cryocooled superconducting magnet.

\begin{tabular}{|c|c|c|c|c|}
\hline Items & \multicolumn{2}{|c|}{$\mathrm{Nb}_{3} \mathrm{Sn}$ wire } & \multicolumn{2}{|c|}{ NbTi wire } \\
\hline Wire diameter $(\mathrm{mm})$ & 1.85 & 1.80 & 2.00 & 1.60 \\
\hline Reinforcement material & \multicolumn{2}{|c|}{$\mathrm{CuNi}-\mathrm{NbTi}$} & - & - \\
\hline Filament diameter $(\mathrm{mm})$ & 3.5 & 3.5 & 30 & 24 \\
\hline Twist pitch (mm) & 50 & 50 & 50 & 40 \\
\hline Diffusion barrier & \multicolumn{2}{|c|}{$\mathrm{Nb}$} & - & - \\
\hline \multicolumn{5}{|l|}{ Fraction (\%) } \\
\hline $\mathrm{Cu}$ (stabilizer) & 35 & 35 & 67 & 67 \\
\hline Reinforcement materials & 28 & 33 & - & - \\
\hline $\begin{array}{l}\text { Superconducting area } \\
\text { (including } \mathrm{Nb} \text { barrier) }\end{array}$ & 37 & 32 & 33 & 33 \\
\hline Insulation material & \multicolumn{2}{|c|}{ E-glass } & \multicolumn{2}{|c|}{ Polyvinyl formal } \\
\hline $0.2 \%$ proof stress $(\mathrm{MPa})$ (at R.T.) & 330 & 330 & - & - \\
\hline \multicolumn{5}{|l|}{ Critical current (A) (at $4.2 \mathrm{~K})$} \\
\hline $7 \mathrm{~T}$ & - & - & - & 1220 \\
\hline $7.5 \mathrm{~T}$ & - & - & 1440 & 1010 \\
\hline $8 \mathrm{~T}$ & - & - & 1170 & 810 \\
\hline $12 \mathrm{~T}$ & 630 & 510 & - & - \\
\hline $13 \mathrm{~T}$ & 520 & 420 & - & - \\
\hline $14 \mathrm{~T}$ & 420 & 340 & - & - \\
\hline
\end{tabular}

Table 2 Major specifications of $\mathrm{CuNi}-\mathrm{NbTi} / \mathrm{Nb}{ }_{3} \mathrm{Sn}$ wires for test coil.

\begin{tabular}{lcc}
\hline Items & $\mathrm{CuNi}-\mathrm{NbTi} / \mathrm{Nb}{ }_{3} \mathrm{Sn}$ & $\mathrm{Cu} / \mathrm{Nb} \mathrm{Sn}$ \\
\hline Wire diameter $(\mathrm{mm})$ & 1.0 & 1.0 \\
\hline Reinforcement & $\mathrm{CuNi}-\mathrm{NbTi}$ & - \\
\hline Filament diameter $(\mu \mathrm{m})$ & 3.5 & 4.1 \\
\hline Twist pitch $(\mathrm{mm})$ & 32 & $\mathrm{Nb}$ \\
\hline Diffusion barrier & $\mathrm{Nb}$ & 50.0 \\
\hline Fraction (\%) & & - \\
Cu (stabilizer) & 26.5 & 50.0 \\
Reinforcement materials & 22.2 & 150 \\
Superconducting area & 51.3 & 309 \\
(including Nb barrier) & & 222 \\
\hline 0.2\% proof stress (MPa) (at R.T.) & 340 & \\
\hline Critical current (A) (at 4.2 K) & 293 & \\
10T & 209 & \\
$12 \mathrm{~T}$ & & \\
\hline
\end{tabular}

材が R\&W 法によるコイル化に絶えうることを，繰り返し曲 げ後の $I_{\mathrm{c}}$ 測定により確認した後, コイル製作に移行した. 熱処理済の高強度 $\mathrm{Nb}_{3} \mathrm{Sn}$ 線材を $50 \mathrm{MPa}$ の張力で, エポキシ 樹脂にて塗り込みながら R\&W 法によりコイル製作を行った. Table 3 にコイル緒元を示す. コイルは, 内径 $260 \mathrm{~mm}$, 外 径 $289 \mathrm{~mm}$, 高さ $319 \mathrm{~mm}$ であり, $180 \mathrm{~A}$ の通電によりコイル 中心で $2.18 \mathrm{~T}$ の磁場を発生させる設計としている. 中心 で 2.18 T の磁場を発生させたとき, 線材に加わるフープ 力は BJRより $49.2 \mathrm{MPa}$ と求められる. 但し, BJRにおける $B$ は線材に加わる外部磁場, Jはコイル電流密度, Rはコイ ル半径である. テストコイルの外観写真を Fig. 2 に示す. 励磁中のコイル温度の変化を測定するため, コイルの中央 部分外側にカーボングラス測温抵抗体を取り付けている. 作製したコイルの通電試験は, 冷凍機冷却のクライオスタ
ットに組み込んで実施した．なお， $\mathrm{Nb}_{3} \mathrm{Sn}$ コイルに加わる フープ力を大きくするため, バックアップ磁場を印加する ことを考慮して, $\mathrm{Nb}_{3} \mathrm{Sn}$ コイルの外側に NbTi コイルを組み 込んだ.バックアップ磁場用の NbTi コイルは, 内径 $317 \mathrm{~mm}$, 外径 $380 \mathrm{~mm}$, 高さ $377 \mathrm{~mm}$ であり, $220 \mathrm{~A}$ の通電でコイル 中心に $5.85 \mathrm{~T}$ の磁場を発生させる. コイル試験装置の概 略を Fig. 3 に示す. GM-冷凍機 2 台を用いて $\mathrm{Nb}_{3} \mathrm{Sn}$ および $\mathrm{NbTi}$ の超電導コイルを $4 \mathrm{~K}$ まで冷却する。.また, $\mathrm{Nb}_{3} \mathrm{Sn}$ コ イル, NbTi コイルの設計電流值が異なるため, 通電はそれ ぞれ別系統で行い, 熱侵入を低減させるために, 各電流ラ インの途中には, 外径 $23 \mathrm{~mm}$, 内径 $20 \mathrm{~mm}$, 長さ $120 \mathrm{~mm}$ の 円筒型の (Bi, Pb) ${ }_{2} \mathrm{Sr}_{2} \mathrm{Ca}_{2} \mathrm{Cu}_{3} \mathrm{O}_{\mathrm{x}}$ 高温超電導電流リードを用 いている. 
Table 3 Major specifications of $\mathrm{CuNi}-\mathrm{NbTi}_{\mathrm{N}} \mathrm{Nb}_{3} \mathrm{Sn}$ test coil fabricated by React and Wind technique.

\begin{tabular}{|c|c|c|}
\hline Items & Inner section & Outer section \\
\hline Inner diameter $(\mathrm{mm})$ & 260 & 276 \\
\hline Outer diameter $(\mathrm{mm})$ & 276 & 289 \\
\hline Coil height (mm) & 319 & 319 \\
\hline Number of layers & 8 & 6 \\
\hline Number of turns & 2316 & 1736 \\
\hline Coil constant (T/A) & \multicolumn{2}{|c|}{0.012} \\
\hline Operating current (A) & \multicolumn{2}{|c|}{180} \\
\hline Central field generation & \multicolumn{2}{|c|}{2.18} \\
\hline$B J R(\mathrm{MPa})$ & \multicolumn{2}{|c|}{49.2} \\
\hline Impregnation material & \multicolumn{2}{|c|}{ Epoxy resin } \\
\hline
\end{tabular}

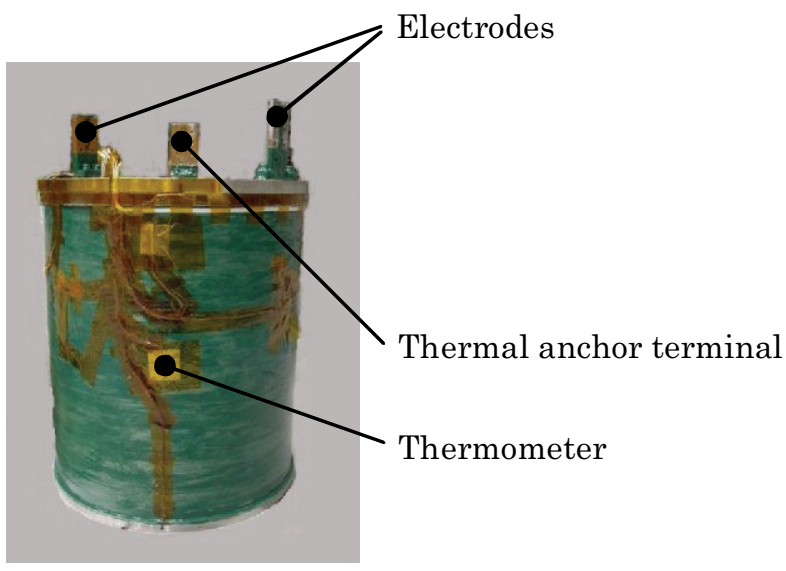

Fig. 2 The $\mathrm{CuNi}-\mathrm{NbTi} / \mathrm{Nb}_{3} \mathrm{Sn}$ test coil by the react and wind technique.

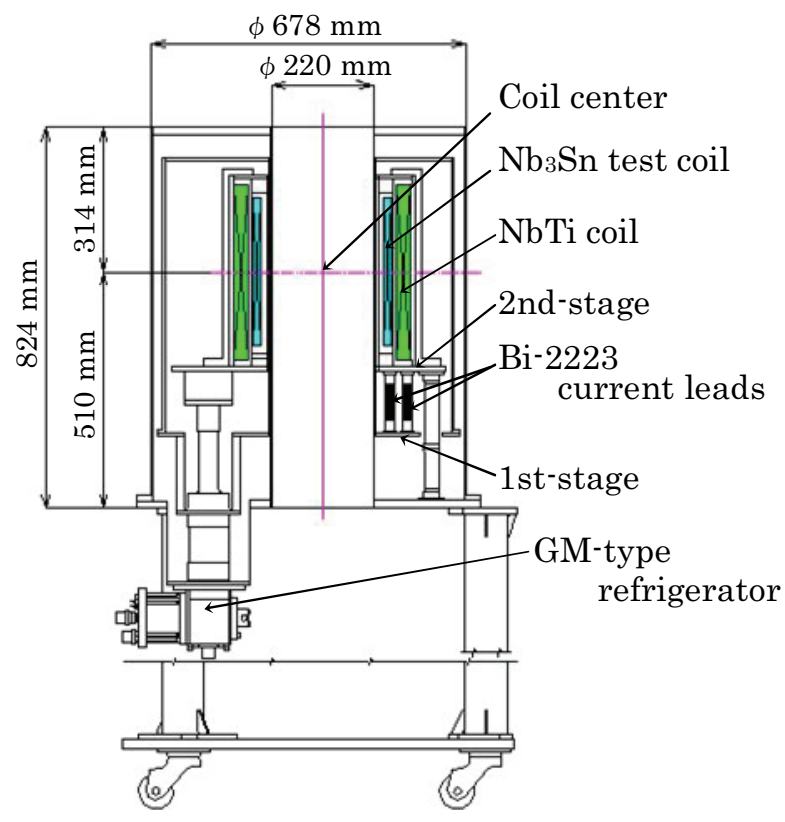

Fig. 3 A schematic view of the cryostat for $\mathrm{CuNi}-\mathrm{NbTi} /$ $\mathrm{Nb}_{3} \mathrm{Sn}$ test coil.

\section{2.2 テストコイルの性能評価}

$\mathrm{Nb}_{3} \mathrm{Sn}$ コイル単体での性能試験結果を Fig. 4 に示す. Fig. 4 は, $\mathrm{Nb}_{3} \mathrm{Sn}$ コイルに通電したときのコイル温度, Gifford-McMahon（G-M）冷凍機の 2nd-stage 温度の時間変 化を示している.コイルの最低到達温度は $4 \mathrm{~K}$ 以下となり, 十分冷却されていることがわかる. $\mathrm{Nb}_{3} \mathrm{Sn}$ コイル単体での 励磁では, ヒステリシス損に起因する, 通電直後からのコ イル温度上昇が見られ, 約 $6 \mathrm{~K}$ まで上昇している. その後, 電流值を $180 \mathrm{~A}$ に保持すると同時に, コイル温度は下がり 始め, 約 4 K で安定していることがわかる. 180 A の電流 值で約 2 時間保持した後, 電流值を下げ始めると, 再度, ヒステリシス損による, 温度上昇が観察される. $\mathrm{Nb}_{3} \mathrm{Sn}$ コ イル単体での通電試験により, 単体では $180 \mathrm{~A}$ 通電が可能 であることを確認できた。

次に, $\mathrm{Nb}_{3} \mathrm{Sn}$ 線材に加わるフープ力を大きくするために, バックアップ磁場中での $\mathrm{Nb}_{3} \mathrm{Sn}$ コイルの通電試験を行い, その結果をFig. 5 に示す.NbTi コイルに 220 A まで通電し, コイル中心で $5.85 \mathrm{~T}$ 発生させた状態で, $\mathrm{Nb}_{3} \mathrm{Sn}$ コイルに通 電している. Fig. 5 において, バックアップ磁場の励磁開 始直後および $\mathrm{Nb}_{3} \mathrm{Sn}$ コイルの励磁開始直後において, $\mathrm{Nb}_{3} \mathrm{Sn}$ コイルの温度上昇が見られるが，この温度上昇は， $\mathrm{Nb}_{3} \mathrm{Sn}$ コイルの単体通電時と同様にヒステリシス損に起因する と考えられる. 5.85 T のバックアップ磁場中では, 長時間 安定して $\mathrm{Nb}_{3} \mathrm{Sn}$ コイルへ通電できるのは $130 \mathrm{~A}$ であり, 約 6 時間の保持を確認した。 なお， 6 時間後のコイル温度は 7.5 K で安定していた。また，最大では $140 \mathrm{~A}$ の通電まで可 能であり, $140 \mathrm{~A}$ でクエンチ寸る直前の $\mathrm{Nb}_{3} \mathrm{Sn}$ コイルの温 度は 8 K であった。

スケーリング則より求めた高強度 $\mathrm{Nb}_{3} \mathrm{Sn}$ 線の $I_{\mathrm{c}}$ - $B$ 特性と $\mathrm{R} \& \mathrm{~W}$ 法により作製した今回の $\mathrm{Nb}_{3} \mathrm{Sn}$ コイルのロードライ ンをFig. 6 に示す。また, $\mathrm{Nb}_{3} \mathrm{Sn}$ コイルに $130 \mathrm{~A}$ および 140 A 通電したときに，コイルを構成している線材に加わるそ れぞれの歪を, Table 4 に示す. Fig. 6 より $130 \mathrm{~A}$ 通電時 の最大経験磁場 $8.07 \mathrm{~T}$ において， I K であるため, $250 \mathrm{~A}$ と求められる。同様にして, $140 \mathrm{~A}$ 通 電時の最大経験磁場 $8.21 \mathrm{~T}$ において， $I_{\mathrm{c}}$ は，コイル温度 
が 8 K であるため, 213 A と求められる. 但し, Fig. 6 の $I_{\mathrm{c}}-B$ 特性は, 歪のないストレート短線からのデータを基に しており，コイル形状にしたときの特性とは異なる。この ため, 今回のコイル形状において, 実際に線材に加わって いる歪を検討し, その歪が加わった状態での $I_{\mathrm{c}}$ について考 察する. Table 4 より, 巻枠への巻線による曲げ (巻枠の

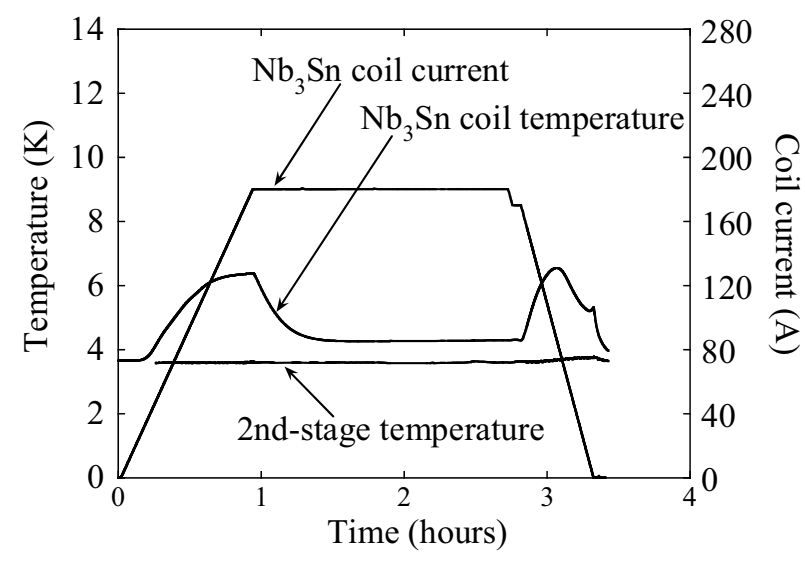

Fig. 4 Performance results of the $\mathrm{CuNi}-\mathrm{NbTi} / \mathrm{Nb}_{3} \mathrm{Sn}$ test coil fabricated by the React and Wind technique.

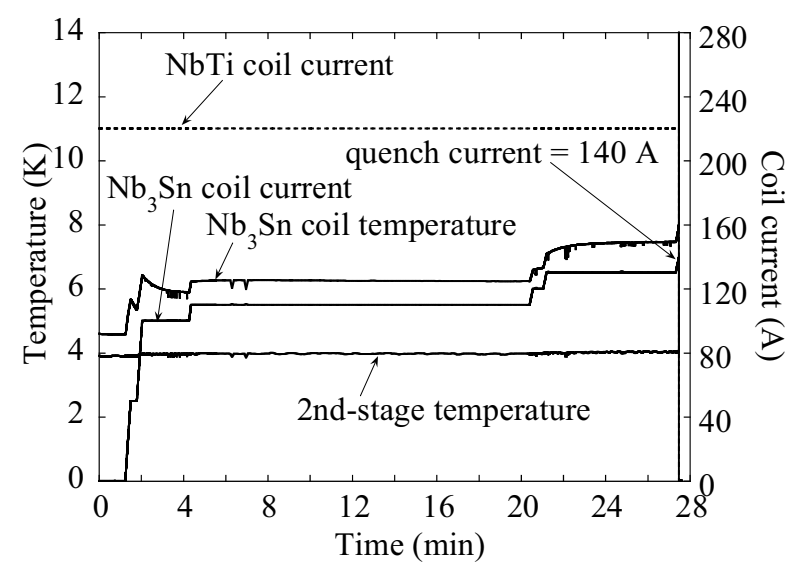

Fig. 5 Performance results of the $\mathrm{CuNi}-\mathrm{NbTi} / \mathrm{Nb}_{3} \mathrm{Sn}$ test coil fabricated by the React and Wind technique in the buckup coil.
直径は $260 \mathrm{~mm})$ により, 歪は 0.38 \% と算出され，また， コイル巻線時の張力 $50 \mathrm{MPa} よ り$, 本線材の低歪域でのヤ ング率 $67 \mathrm{GPa}^{8)}$ を用いて, 歪は $0.07 \%$ と算出される.これ ら 2 つ歪は，コイル化した時点で既に線材に加わってお り，コイルに通電することにより，さらにフープ力が加わ ることとなる. Table 4 に示すように，コイルへの $130 \mathrm{~A}$ 通電時, フープ力は $B J R$ より $119 \mathrm{MPa}$ となるため, 歪は $0.18 \%$ となり，合計歪は $0.63 \%$ となる.また，コイルへ の $140 \mathrm{~A}$ 通電時, フープ力は $131 \mathrm{MPa}$ となるため歪は $0.20 \%$ となり, 合計歪は $0.65 \%$ となる. したがって, どちらの通 電においても， 0.6 \%以上の大きな歪が加わっていること となる。

ここで, 歪と $I_{\mathrm{c}}$ の関係を明らかにしておくため, 本線材 と構成部材が同一，かつ，構成比もほぼ同等である線材に 関する三好らの報告 ${ }^{9)}$ table 5 にまとめ，今回の歪がか かった状態での $I_{\mathrm{c}}$ を算出した. なお, Table 5 において, 歪が加わっていない状態で規格化した值 $\left(I_{\mathrm{c}} / I_{\mathrm{c} 0}\right)$ で， $I_{\mathrm{c}}$ を表記し，比較のため，通常のブロンズ法 $\mathrm{Nb}_{3} \mathrm{Sn}$ 線の值に ついても併記している. Table 5 より, $\mathrm{Nb}_{3} \mathrm{Sn}$ コイルに 130 A 通電したときの 0.63 \%の歪がかかった状態において, $I_{\mathrm{c}} / I_{\mathrm{c} 0}$ は 73 \%となっており, また, $140 \mathrm{~A}$ 通電したときの $0.65 \%$ 歪がかかった状態において， $I_{\mathrm{c}} / I_{\mathrm{c} 0}$ は 70 \%となっ

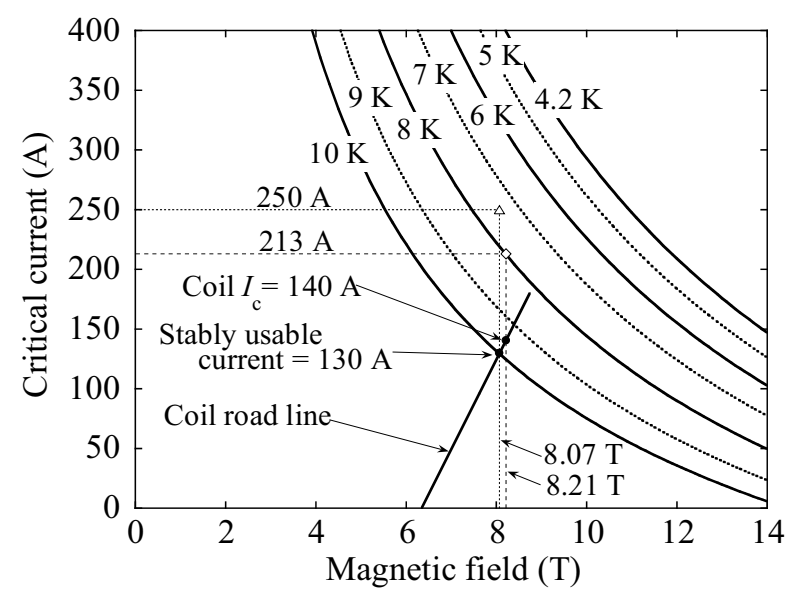

Fig. $6 \quad I^{-}-B$ curves and load line of the $\mathrm{CuNi}-\mathrm{NbTi} /$ $\mathrm{Nb}_{3} \mathrm{Sn}$ test coil fabricated by the React and Wind technique in the buckup coil.

Table 4 Strains of $\mathrm{CuNi}-\mathrm{Nb}^{\mathrm{Ti}} / \mathrm{Nb}_{3} \mathrm{Sn}$ test coil.

\begin{tabular}{lcc}
\hline \multicolumn{1}{c}{ Items } & Operating current of $\mathrm{Nb}_{3}$ Sn test coil (A) & 140 \\
\cline { 2 - 3 } & 130 & 0.38 \\
\hline Winding & 0.38 & 0.07 \\
Bending strain (\%) & 0.07 & 131 \\
Tensile strain (\%) & 119 & 0.20 \\
\hline Hoop stress (MPa) & 0.18 & 7.55 \\
\hline Hoop strain (\%) & 7.42 & 8.21 \\
\hline Central field generation (T) & 8.07 & 0.65 \\
\hline$B_{\text {max }}(\mathrm{T})$ & 0.63 & \\
\hline Total strain (\%) & & \\
\hline
\end{tabular}


Table 5 Strain dependence of $I_{\mathrm{c}}$ at $4.2 \mathrm{~K}, 14.5 \mathrm{~T}$ in $\mathrm{CuNi}-\mathrm{NbTi} / \mathrm{Nb}_{3} \mathrm{Sn}$ wire and $\mathrm{Cu} / \mathrm{Nb}_{3} \mathrm{Sn}_{\text {wire. }}$

\begin{tabular}{ccc}
\hline \multirow{2}{*}{ Strain $(\%)$} & \multicolumn{2}{c}{ Normalized $I_{\mathrm{c}}\left(I_{\mathrm{c}} / I_{\mathrm{c} 0}\right)^{9)}$} \\
\cline { 2 - 3 } & $\mathrm{CuNi}-\mathrm{NbTi} / \mathrm{Nb}{ }_{3} \mathrm{Sn}$ & $\mathrm{Cu} / \mathrm{Nb} 3 \mathrm{Sn}$ \\
\hline 0.63 & 0.73 & 0.42 \\
0.65 & 0.70 & 0.23 \\
\hline
\end{tabular}

Table 6 Major specifications of superconducting coils for 10T- $\phi 360 \mathrm{~mm}$ magnet.

\begin{tabular}{|c|c|c|c|c|}
\hline \multirow{2}{*}{ Items } & \multicolumn{2}{|c|}{ Inner coil } & \multicolumn{2}{|c|}{ Outer coil } \\
\hline & Section A & Section B & Section $\mathrm{C}$ & Section D \\
\hline Superconducting wire & \multicolumn{2}{|c|}{$\mathrm{CuNi}-\mathrm{NbTi} / \mathrm{Nb}_{3} \mathrm{Sn}$} & \multicolumn{2}{|c|}{$\mathrm{NbTi}$} \\
\hline Wire diameter $(\mathrm{mm})$ & 1.85 & 1.80 & 2.00 & 1.60 \\
\hline Coil inner diameter $(\mathrm{mm})$ & 400 & 495 & 605 & 670 \\
\hline Coil outer diameter $(\mathrm{mm})$ & 480 & 580 & 665 & 755 \\
\hline Coil height (mm) & 400 & 450 & 500 & 550 \\
\hline Number of turns & 4350 & 5490 & 3860 & 6570 \\
\hline Wire length $(\mathrm{km})$ & 6.0 & 9.2 & 7.7 & 14.9 \\
\hline Operating current (A) & 246 & 246 & 350 & 350 \\
\hline Current density $\left(\mathrm{A} / \mathrm{mm}^{2}\right)$ & 70 & 73 & 93 & 143 \\
\hline Critical temperature (K) & 8.5 & 9.5 & 6.5 & 7.5 \\
\hline Maximum magnetic field (T) & 11.3 & 8.5 & 5.5 & 2.6 \\
\hline Central field generation $(\mathrm{T})$ & 2.3 & 2.4 & 2.1 & 3.2 \\
\hline Total magnetic field (T) & & & & \\
\hline Stored energy (MJ) & & & & \\
\hline Hoop stress (MPa) & 160 & 155 & 155 & 130 \\
\hline
\end{tabular}

ている．前述より， $130 \mathrm{~A}$ 通電時における $8.07 \mathrm{~T}, 7.5 \mathrm{~K}$ の条件では, $250 \mathrm{~A}$ の $I_{\mathrm{c}}$ であるため, 0.63 \%の歪を考慮す ると, 250 A×73 \%より 183 A の $I_{\mathrm{c}}$ が得られる. しかしな がら，今回安定して通電可能であった值は 130 A であり， $I_{\mathrm{c}}(=183 \mathrm{~A})$ の 71 \%に留まっている. また, $140 \mathrm{~A}$ 通電時 における $8.21 \mathrm{~T}, 8 \mathrm{~K}$ の条件では, $213 \mathrm{~A}$ の $I_{\mathrm{c}}$ であるため, $0.65 \%$ の歪を考慮すると， $213 \mathrm{~A} \times 70$ \%より $150 \mathrm{~A} の I_{\mathrm{c}}$ が 得られる.したがって，作製したテストコイルの $I_{\mathrm{c}}$ は歪を 考慮したときの $I_{\mathrm{c}}$ の 94 \%となり，100\%とはならなかった が, コイル内部に温度分布があり, 局所的に $8 \mathrm{~K}$ 以上とな りうることを考慮すると, $6 \%$ 差は十分予想される範囲で あると考えられる. また, 通常のブロンズ法 $\mathrm{Nb}_{3} \mathrm{Sn}$ 線にお いては，0.63\%の歪では $I_{\mathrm{c}} / I_{\mathrm{c} 0}$ が 43 \%となり，0.65\%の歪 では $I_{\mathrm{c}} / I_{\mathrm{c} 0}$ が $23 \%$ となり，0.6\%以上の歪により $I_{\mathrm{c}}$ が大き く低下してしまうことが確認できる. 今回のテストコイル 評価により, 高強度 $\mathrm{Nb}_{3} \mathrm{Sn}$ 線材および $\mathrm{Nb}_{3} \mathrm{Sn}$ コイルの R \& W 製作方法が, 実用に耐えうることを確認できた. ところで, $10 \mathrm{~T}-\phi 360 \mathrm{~mm}$ 冷凍機冷却超電導マグネット用の実機 $\mathrm{Nb}_{3} \mathrm{Sn}$ コイルはW \& R 法にて製作するため, コイル化した時点で は構成線材に歪は加わらず, 歪に関しては通電時のフープ 力のみを考慮すれば良いことになる。このため，テストコ イルよりも実機 $\mathrm{Nb}_{3} \mathrm{Sn}$ コイルの方が, リスクを低減できる と考えられる.

\section{3 実機超電導コイルの設計}

$10 \mathrm{~T}-\phi 360 \mathrm{~mm}$ 冷凍機冷却超電導マグネット用の超電 導コイルの諸元を Table 6 に示す. これまでの強磁場超電 導マグネットと同様に ${ }^{1)}{ }^{4)}$,5), コイルは大別して, 内側に
$\mathrm{Nb}_{3} \mathrm{Sn}$ コイル，その外側に NbTi コイルを配置した構成とな っている.さらに，各コイルはそれぞれ 2 つのクション に分割され, 合計で 4 つコイルによって構成されている. なお，4つのコイルは，コイルボビンを別々としており， グレーディングによる巻き線時の巻き乱れを，防止できる 構造としている. Table 6 に示すように, 各セクションの コイルにおいて，使用する線材の線径を変化させてグレー ディングし，また，高さを調整することでコイル全体とし て小型化を図り, その結果, コイル巻線重量を $1 \mathrm{t}$ 未満と なる， $851 \mathrm{~kg}$ に抑えることができた．液体へリウム浸漬冷 却方式による従来型の超電導マグネットでは, ほぼ同等仕 様とした場合, コイル外径 $1121 \mathrm{~mm}$, 高さ $680 \mathrm{~mm}$, コイル 巻線重量 $3800 \mathrm{~kg}$ であり ${ }^{10)}$ ，コイル重量で約 $1 / 4$ まで小型 化できている. 内側の $\mathrm{Nb}_{3} \mathrm{Sn}$ コイルは, 線径 $\phi 1.85 \mathrm{~mm}$ の線 材よりなるセクション A コイルと, 線径 $\phi 1.80 \mathrm{~mm}$ の線材 よりなるセクション B コイルとによって構成されている. 定格の $10 \mathrm{~T}$ を励磁したとき, Section $\mathrm{A}$ の $\mathrm{Nb}_{3} \mathrm{Sn}$ コイルで 最大経験磁場は $11.3 \mathrm{~T}$ となり, フープ力は BJRより算出 して $160 \mathrm{MPa}$ となった。同様にして, Section B の $\mathrm{Nb}_{3} \mathrm{Sn}$ コイルには, $155 \mathrm{MPa}$ のフープカが加わることとなる. し たがって，どちらの $\mathrm{Nb}_{3} \mathrm{Sn}$ コイルにも $150 \mathrm{MPa}$ 以上のフー プ力が加わることとなり, 高強度 $\mathrm{Nb}_{3} \mathrm{Sn}$ 線が必要であるこ とがわかる，また，160 MPa の応力下では，高強度 $\mathrm{Nb}_{3} \mathrm{Sn}$ 線に加わる歪は，ヤング率 $67 \mathrm{GPa}^{8)}$ を用いて 0.23 \%と算出 され，本歪では $I_{\mathrm{c}}$ 低下は殆どないことから ${ }^{9)}$, 本コイルに 十分使用可能であることがわかる。一方，外側の $\mathrm{NbTi} コ$ イルは, 線径 $\phi 2.00 \mathrm{~mm}$ の線材よりなるセクションCコイ 
Table 7 Estimated heat loads of $10 \mathrm{~T}-\phi 360 \mathrm{~mm}$ superconducting magnet.

\begin{tabular}{|c|c|c|c|c|}
\hline \multirow{2}{*}{ Heat load } & \multicolumn{2}{|c|}{ No operating current } & \multicolumn{2}{|c|}{ Full energized } \\
\hline & Inner coil & Outer coil & Inner coil & Outer coil \\
\hline Operating current $(\mathrm{A})$ & 0 & 0 & 246 & 350 \\
\hline \multicolumn{5}{|l|}{ 1st-stage } \\
\hline Copper current leads (W) & \multicolumn{2}{|c|}{21.3} & \multicolumn{2}{|c|}{38.2} \\
\hline Measuring wires (W) & \multicolumn{2}{|c|}{0.4} & \multicolumn{2}{|c|}{0.4} \\
\hline Radiation (W) & \multicolumn{2}{|c|}{26.0} & \multicolumn{2}{|c|}{26.0} \\
\hline Joule heating $(\mathrm{W})$ & \multicolumn{2}{|c|}{0} & \multicolumn{2}{|c|}{8.5} \\
\hline Support structures (W) & \multicolumn{2}{|c|}{6.3} & \multicolumn{2}{|c|}{6.3} \\
\hline Total (W) & \multicolumn{2}{|c|}{54.0} & \multicolumn{2}{|c|}{79.5} \\
\hline \multicolumn{5}{|l|}{ 2nd-stage } \\
\hline $\mathrm{Bi}-2223$ current leads (W) & \multicolumn{2}{|c|}{0.18} & \multicolumn{2}{|c|}{0.18} \\
\hline Measuring wires (W) & \multicolumn{2}{|c|}{0.20} & \multicolumn{2}{|c|}{0.20} \\
\hline Radiation (W) & \multicolumn{2}{|c|}{0.05} & \multicolumn{2}{|c|}{0.05} \\
\hline Joule heating (W) & \multicolumn{2}{|c|}{0} & \multicolumn{2}{|c|}{0.86} \\
\hline Support structures (W) & \multicolumn{2}{|c|}{0.46} & \multicolumn{2}{|c|}{0.46} \\
\hline AC losses & \multicolumn{2}{|c|}{0} & \multicolumn{2}{|c|}{2.75} \\
\hline Total (W) & \multicolumn{2}{|c|}{0.89} & \multicolumn{2}{|c|}{4.50} \\
\hline
\end{tabular}

ルと, 線径 $\phi 1.60 \mathrm{~mm}$ の線材よりなるセクション D コイル から構成されており, NbTi コイルへ加わるフープ力は, セ クションCコイルに加わる $155 \mathrm{MPa}$ が最大となっている. $\mathrm{NbTi}$ 線は機械的強度の 1 つの指針となる 0.2 \%而力で 500 $\mathrm{MPa}$ を示し, 今回の $155 \mathrm{MPa}$ のフープ力による歪では $I_{\mathrm{c}}$ の 劣化は殆どないことから ${ }^{11)}$, 今回開発する超電導コイルに は従来の NbTi 線にて対応可能と判断できる. また, $\mathrm{Nb}_{3} \mathrm{Sn}$ コイルへの電流負荷を低減するため, $\mathrm{Nb}_{3} \mathrm{Sn}$ コイルの通電電 流值を $\mathrm{NbTi}$ コイルの通電電流值よりも低く設計し, このた め, 通電電流ラインを 2 系統とした. $\mathrm{Nb}_{3} \mathrm{Sn}$ コイルへ $246 \mathrm{~A}$ 通電し, NbTi コイルへ $350 \mathrm{~A}$ 通電したとき, コイル中心で 10 T の磁場が発生する.

コイル中心で $10 \mathrm{~T}$ の磁場を発生させたとき, 蓄積エネル ギーは $6.5 \mathrm{MJ}$ となり，これまでに我々が製作してきた冷凍 機冷却超電導マグネットに比べて, 最大の蓄積エネルギー となる。

\section{4 熱設計}

冷凍機冷却超電導マグネットにおける超電導コイルの冷 却は，冷凍機による伝導冷却であるため，マグネットシス テム全体としての熱設計が重要となる．この熱設計を基に して, G-M 冷凍機の必要能力および台数が決定される. コ イルに無通電時および定格電流通電時の熱設計值を, Table 7 に示す. 無通電時において, G-M 冷凍機の 1 段ステージへ の熱負荷は, $\mathrm{Cu}$ 電流リードの伝導熱である $21.3 \mathrm{~W}$ と輻射 熱の 26.0 W とで大半を占め, 合計では 54.0 W となってい る.また, G-M 冷凍機の 2 段ステージへの熱負荷は, 荷重 支持体からの伝導熱である 0.46 W が最も大きく，合計では $0.89 \mathrm{~W}$ となっている. 一方, 定格電流を通電して, $10 \mathrm{~T} の$ 磁場発生時においては, 1 段ステージへの熱負荷は, ジュ 一ル発熱分が無通電時の熱負荷に加算され, 合計で $79.5 \mathrm{~W}$ となっている。また， 2 段ステージへの熱負荷は，交流損 失のよる発熱とジュール発熱が無通電時の熱負荷に加算さ れ, 合計で 4.50 W となっている. ここで, 設計電流を通電

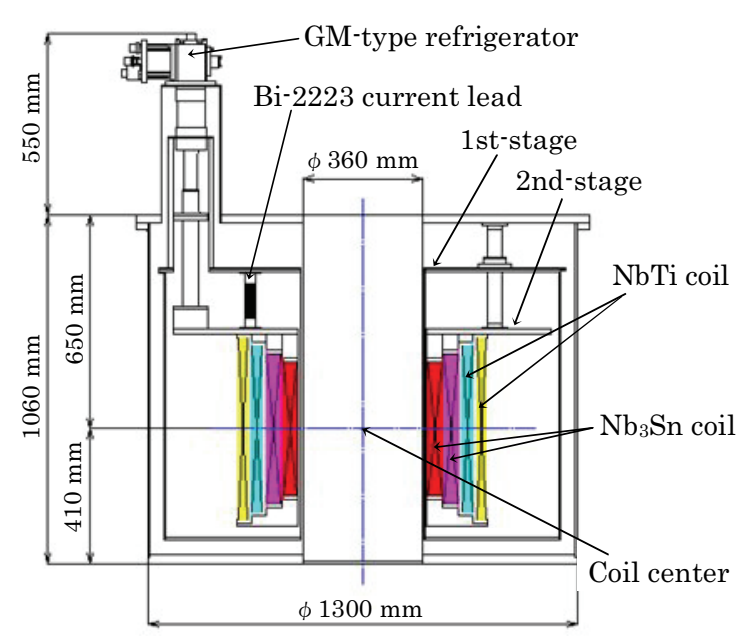

Fig. 7 Schematic view of the 10T- $\phi 360 \mathrm{~mm}$ superconducting magnet.

したとき， 2 段ステージには交流損失による大きな熱負荷 2.75 Wが加わっているが，この計算には，想定される最大 挿引速度である $0.175 \mathrm{~A} / \mathrm{s}$ を用いている. 以上の計算結果 から，1 段ステージの冷凍能力が 35 W/50 K, 2 段ステージ の冷凍能力が 1.5 W/4.2 K を有する, G-M 冷凍機を 4 台用 いることとした．このとき，G-M 冷凍機 1 台当たりの熱負 荷は，定格電流通電時，1 段ステージに 19.85 W, 2 段ステ ージに 1.13 W となり, したがって, コイル温度は $4.2 \mathrm{~K}$ 以 下に冷却されることがわかる.

\section{5 超電導マグネット}

作製した10 T- $\phi 360$ mm冷凍機冷却超電導マグネットの概 略をFig. 7に, 外観写真をFig. 8にそれぞれ示す. 超電導マ グネットは外径 $1300 \mathrm{~mm}$, 高さ $1610 \mathrm{~mm}$ であり, 直径 $360 \mathrm{~mm}$ の貫通した室温ボアを有しており，G-M冷凍機4台を用いて 超電導コイルが冷却される. また, 通電電流に関しては, 外側のNbTiコイルと内側の $\mathrm{Nb}_{3} \mathrm{Sn}$ コイルとで電流值が異な り,2台の電源を用いてそれぞれのコイルへ別系統で通電す 


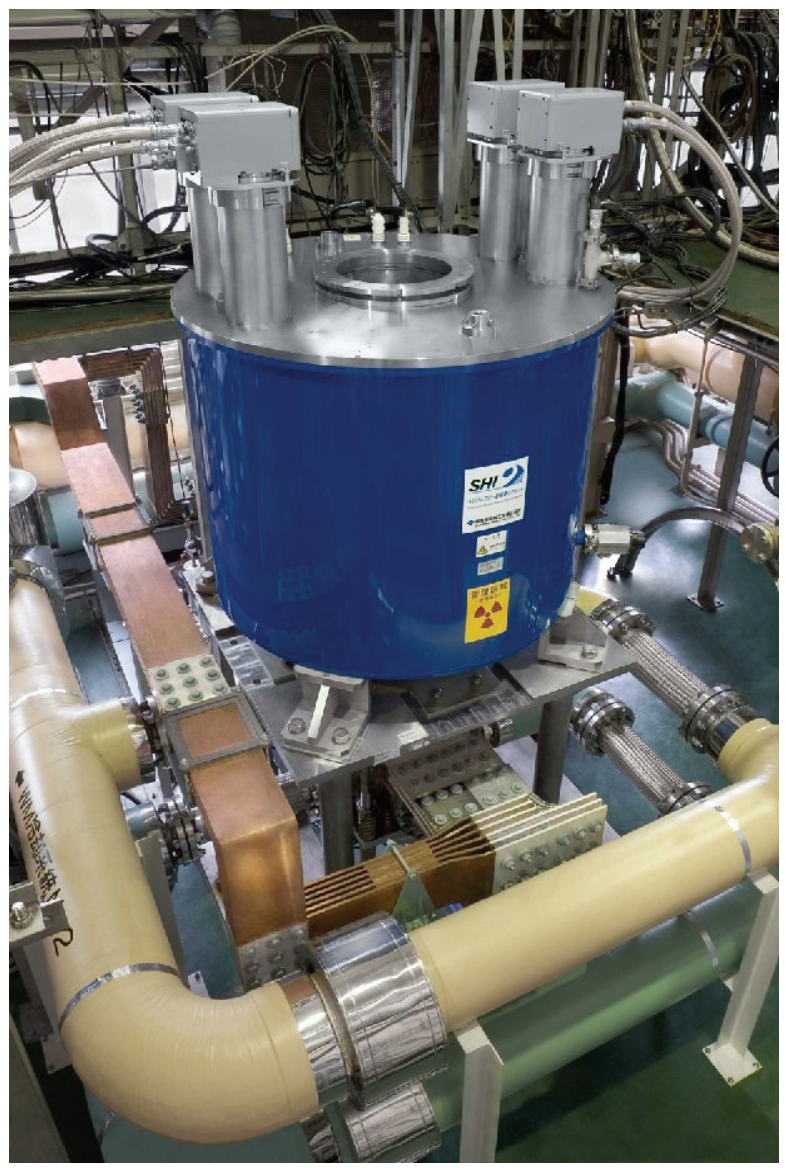

Fig. 8 Photograph of the 10T- $\phi 360 \mathrm{~mm}$ superconducting magnet.

るため, 本超電導マグネットは $2 つ の$ 電流ラインを有してい る. さらに, 超電導コイルへの熱侵入を低減するため, Fig. 7 に示すように, $(\mathrm{Bi}, \mathrm{Pb}){ }_{2} \mathrm{Sr}_{2} \mathrm{Ca}_{2} \mathrm{Cu}_{3} \mathrm{O}_{\mathrm{x}}$ 高温超電導電流リードを, 1st-stage と 2 nd-stage との間の電流供給ラインに用いてお り, 電流ラインが2系統であるため, 合計 4 本の高温超電導 電流リードを使用している. なお, 本マグネットはこれま での冷凍機冷却超電導マグネットに比べて, 電流值および 漏洩磁場が大きいことから，Icを増やすために断面積を大 きくして，外径 $33 \mathrm{~mm}$, 内径 $30 \mathrm{~mm}$, 長さ $120 \mathrm{~mm}$ としいる. この断面積増加により, 従来の超電導電流リードに比べ, $I_{\mathrm{c}}$ は1.5倍以上となり，1500 A（@77 K, 自己磁場）以上 を示している.

\section{3. 試験結果および考察}

\section{1 初期冷却}

初期冷却における超電導コイルと熱シールドの温度変化 をFig. 9に示す. 超電導コイルに関しては, $\mathrm{Nb}_{3} \mathrm{Sn}$ コイルの 電極部, $\mathrm{NbTi}$ ユイルの電極部および冷凍機より離れた $\mathrm{Nb}_{3} \mathrm{Sn}$ コイルの底部の3箇所を, セルノックス測温抵抗体により温 度計測している。また, 熱シールドに関しては, 冷凍機に 近い上部と冷凍機から最も離れた底部の2箇所を, セルノッ

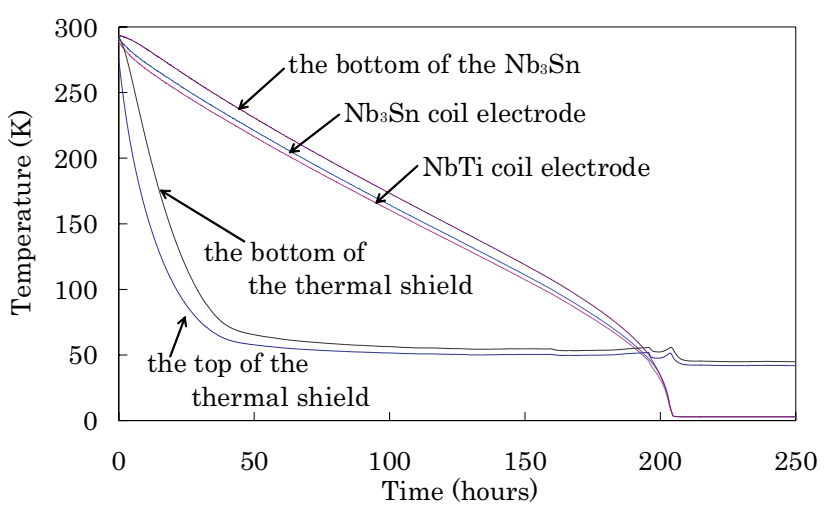

Fig. 9 Coil and thermal shield temperatures as a function of time during initial cooldown.

クス測温抵抗体により温度計測している。冷却を開始して から約215時間後に, 超電導コイルの温度が約 $3 \mathrm{~K}$ 到達し 定常となり，そのときの熱シールド温度は，上部が $42 \mathrm{~K}$ ，下 部が45 Kで定常となった。 熱シールド温度の上部と下部と で，温度差が 3 K生じたのは，上部側に冷凍機が配置されて おり，上部と下部とで温度分布が生じているためと考えら れる. 一方，コイル温度に関しては上下を均熱のための銅 ブスバーで接続しているため, 殆ど温度差は確認されなか った. 冷却被重量から算出した初期冷却時間は約 220 時間で あり，実測值とほぼ一致していることが確認できる。

\section{2 励磁試験結果}

ハイブリッドモードでの励磁試験に先立ち, $10 \mathrm{~T}-\phi 360$ mm冷凍機冷却超電導マグネット単体にて励磁試験を実施し た。まず，外側のNbTiコイルを単体にて励磁試験し，3回の トレーニングを経て，4回目の励磁で設計磁場5.3 T （通電 電流350 A）を達成した。一方, 内側の $\mathrm{Nb}_{3} \mathrm{Sn}$ コイルの励磁 試験は，単体では線材への最大経験磁場が設計值より小さ く, 臨界温度が 12 Kを超えるため, 設計磁場よりも $25 \%$ 増 しの5. 8 T（通電電流303 A）までの励磁試験を行い，その 結果, トレーニング無しで5.8Tを達成した. 以上のように, 各コイル単体での励磁試験による健全性を確認後, 内側の $\mathrm{Nb}_{3} \mathrm{Sn}$ コイル，外側のNbTiコイルを組み合わせて励磁試験を 行った。組み合わせ励磁試験では，安全を考慮して設計磁 場の10 Tよりも5\%低い9.5 Tでの確認試験を行うこととし, その結果, 内側の $\mathrm{Nb}_{3} \mathrm{Sn}$ コイルで4.2 T （通電電流221 A）, 外側のNbTiコイルで5. 3 T（通電電流348 A）の磁場をそれ ぞれ発生させ，合計で9.5 Tの磁場発生を確認した.

超電導マグネット単体での 9.5 Tの磁場発生を確認後, 超 電導マグネットの室温ボア内に設置された水冷銅マグネッ 卜 $(32 \mathrm{~mm}$ の室温ボア）と組み合わせて，ハイブリット励磁 運転を実施した。ハイブリット励磁運転での試験結果を Fig. 10に示す. Fig. 10は, 超電導マグネットで8. 5 Tの磁場 を発生させた後, 水冷銅マグネットで19 Tの磁場を発生さ せ，合計で27.5 Tの磁場を発生させたときの，通電電流， 磁場，温度の関係を時間経過とともに示している．中心で の27.5 T磁場発生は, 冷凍機冷却超電導マグネットを用い 

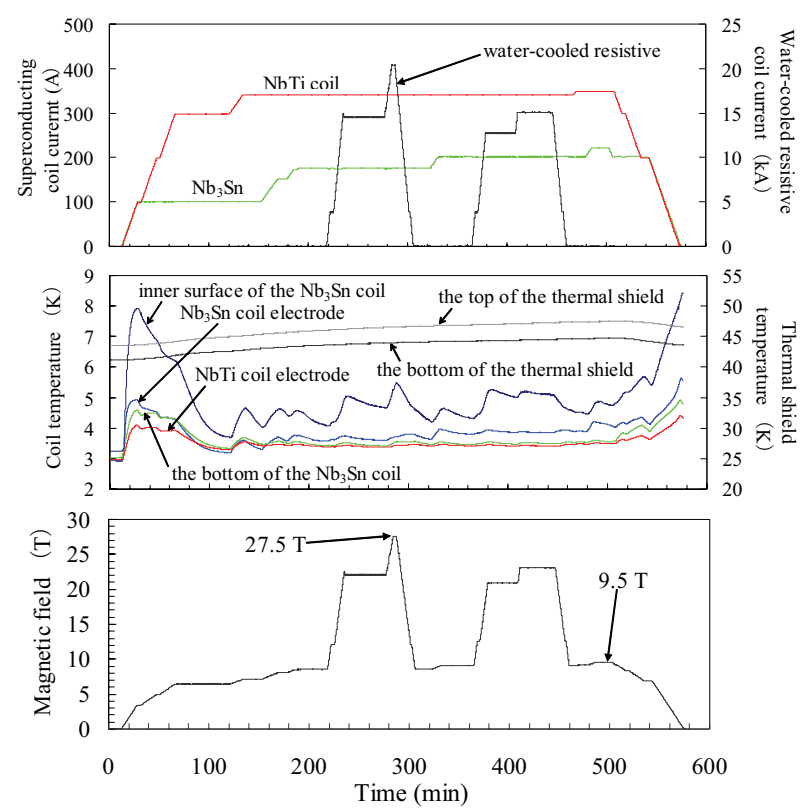

Fig. 10 Performance results of hybrid operation and independent operation of superconducting magnet.

たハイブリッドマグネットとしてはこれまでに報告はなく， 今回が初めてである.

ハイブリッド励磁運転での 27.5 Tの磁場発生後, 水冷銅 マグネットを消磁し, 超電導マグネットの磁場を 8.5 Tから 9.5 Tまで上げて, 9.5 Tの磁場発生を確認している. なお, コイル温度に関しては, $\mathrm{Nb}_{3} \mathrm{Sn}$ コイルの巻枠内側 (中央高さ) にセルノックス測温抵抗体を追加設置し, コイル高さの中 央付近での温度を計測できるようにした。超電導コイル単 体での通電開始直後より, ヒステリシス損失に起因するコ イル温度の上昇が見られ, $\mathrm{Nb}_{3} \mathrm{Sn}$ コイルの巻枠内側では約 $8 \mathrm{~K}$ まで上昇しており，他の測定箇所のコイル温度に比べて $3 \mathrm{~K}$ 以上高くなっている．今回のコイル温度測定により, $\mathrm{Nb}_{3} \mathrm{Sn}$ コイルにおいて少なくとも $3 \mathrm{~K}$ 以上の温度差のある分布が生 じており，コイル中央付近で最も温度が高くなっていると 推察される. 高さ方向に長いコイルを上下より伝導にて冷 却しているため，コイル中央で温度が高くなっていると思 われる(10). 一方, 熱シールド温度に関しては, 27.5 Tの磁 場を発生させたとき, 約 $3 \mathrm{~K}$ の上昇が見られ, シールド上部 と下部とで, 通電開始前の約 $3 \mathrm{~K}$ 温度差がついたままであ った. なお, 28 Tの発生磁場については, 温度上昇による, Section Aコイルのクエンチにより, 確認できていない. Section Aコイルの $T_{\mathrm{c}}$ はTable 6より 8.5 Kであり, 巻枠内側 での約 $8 \mathrm{~K}$ までの温度上昇を考えると, 8.5 K以上となる箇 所も十分存在すると推察され, 温度クエンチの可能性が高 い.

\section{3 磁気科学へのハイブリッドマグネット利用}

強磁場を用いることにより, 磁気力場は通常大きくなり, 水, プラスチック, ガラス等の通常は磁場に応答しない非 常に小さな磁化率の反磁性体等の物質を, 重力に逆らって

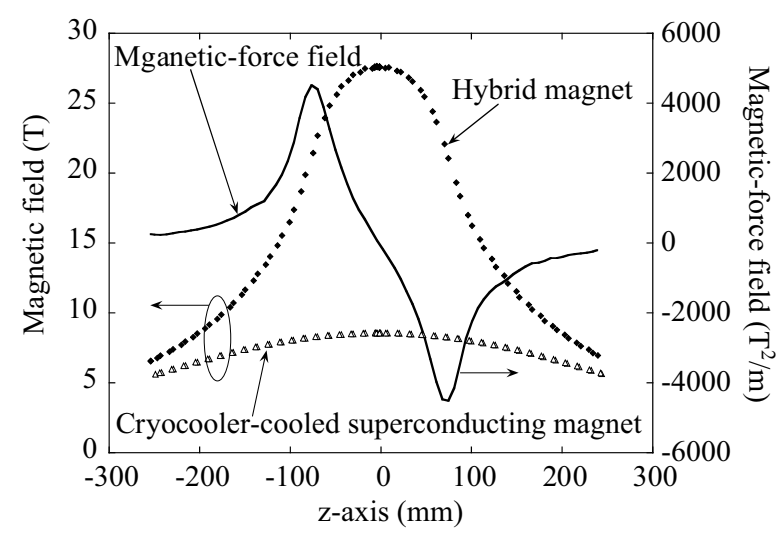

Fig. 11 Calculated magnetic-force field distribution of the hybrid magnet along the $\mathrm{z}^{-}$axis.

浮上させることが可能となる．物質を磁気浮上させた状態 で溶融することにより，坩堝が不用となり，坩堝からの不 純物混入を防ぐことができる，また，磁気浮上により，重 力の影響を排除することができ，熱処理による結晶配向が 有利に働くことも考えられる．磁気科学においては，磁場 強度とともに磁気力場 $(B \cdot d B z / d z)$ は磁気浮上等に重要な 值であると考えられる. 反磁性物質を磁気浮上させるには, その物質の重力と磁気力とが釣り合うことが必要である. 単位質量当たりの磁気力 $F_{\mathrm{w}}$ は次式 (1) より求められる ${ }^{12)}$.

$$
F_{\mathrm{w}}=\chi_{\mathrm{w}} / \mu_{0} \cdot B \cdot d B z / d z . \cdots(1)
$$

ここで， $x_{w}$ は質量磁化率， $\mu_{0}$ は真空の透磁率，Bは磁束 密度, $d B z / d z$ は垂直方向の磁束密度勾配である. 半導体材 料の 1 つであるInSbは $x_{\mathrm{w}}=-3.58 \times 10^{-9} \mathrm{~m}^{3} / \mathrm{kg}$ であり, 磁気浮 上に必要な磁気力場 $(B \cdot d B z / d z)$ は $3440 \mathrm{~T}^{2} / \mathrm{m}$ 以上である ${ }^{12)}$. 室温ボアでの鉛直方向の磁場分布測定結果と, その結果よ り算出した磁気力場 $(B \cdot d B z / d z)$ をFig. 11に示す. 本マグ ネットは, 最大で $4500 \mathrm{~T}^{2} / \mathrm{m}$ の磁気力場が得られ, 従来では 磁気浮上させることができなかった, 磁化率の小さなInSb 半導体材料の浮上が可能となることがわかる.

\section{4. まとめ}

強磁場科学用冷凍機冷却超電導マグネットの開発を行っ た. 本マグネットを開発するにあたり, 高強度 $\mathrm{Nb}_{3} \mathrm{~S}$ 線が必 要となり, テストコイルにてその性能評価を行った結果, 実機コイルに適用可能であることを確認した．高強度 $\mathrm{Nb}_{3} \mathrm{Sn}$ 線を用いて開発した超電導マグネットは, 単体では設計磁 場10 Tに対して9.5 Tまで到達し，水冷銅マグネットとの八 イブリッド運転では, 設計磁場 28 Tに対して 27.5 Tまで到 達した.このときのハイブリッドマグネットの磁気力場 $(B \cdot$ $d B z / d z)$ は最大で $4500 \mathrm{~T}^{2} / \mathrm{m}$ であり, 従来では磁気浮上させ ることができなった磁化率の小さい材料を, 浮上させるこ とができるようになった，今回開発したマグネットは，液 体へリウム補充のための試験中断が不用なため, 長時間の 連続磁気浮上が可能であり, それによって, 新材料開発一 の貢献も期待できる. その他, 強磁場を保持して行う, 磁 
場中での材料評価等にも優位性があり, 磁気浮上したまま での金属溶融あるいは強磁場中での結晶配向, 新材料開発, 材料評価等に利用することが考えられる.

謝辞 本研究の実施にあたり, 高強度 $\mathrm{Nb}_{3} \mathrm{Sn}$ 線材を開発・ 提供してくださった古河電気工業株式会社関係者に感謝致 します。また，本論文の執筆にあたり，実験結果の考察に 関して, ディスカッションさせて頂いた東北大学の濱島教 授に感謝致します。

\section{References}

1) T. Hasebe, J. Sakuraba, K. Jikihara, K. Watazawa, H. Mitsubori, Y. Sugizaki, H. Okubo, Y. Yamada, S. Awaji and K. Watanabe : Adv. Cryo. Eng., 43 (1998).

2) K. Watanabe : J. Cryo. Soc. Jpn., 41 (2006) (in Japanese).

3) K. Watanabe, S. Awaji, M. Motokawa, Y. Mikami, J. Sakuraba and K. Watazawa: Jpn. J. Appl. Phys., 37 (1998).

4) J. Sakuraba, Y. Mikami, K. Watazawa, K. Watanabe and S. Awaji : Supercond. Sci. Technol., 13 (2000).
5) K. Watanabe, G. Nishijima, S. Awaji, K. Takahashi, K. Koyama, M. Motokawa, M. Ishizuka, T. Hasebe and J. Sakuraba : IEEE Trans. Appl. Supercond., 14, 2 (2004).

6) D. S. Easton and C. C. Koch : Adv. Cryo. Eng., 22 (1977).

7) J. W. Ekin : Cryogenics 20 (1980).

8) M. Ishizua, T. Hasebe, T. Itou, T. Tsurudome, J. Sakuraba, K. Miyoshi, G. Nishijima, S. Awaji and K. Watanabe : J. Cryo. Soc. Jpn., 39 (2004) (in Japanese).

9) K. Miyoshi, H. Sakamoto, S. Meguro, G. Nishijima, S. Awajiand K. Watanabe : J. Cryo. Soc. Jpn., 39 (2004) (in Japanese).

10) S. Awaji, G. Nishijima, K. Watanabe, T. Itou, M. Ishizuka and J. Sakuraba : J. Cryo. Soc. Jpn., 41 (2006) (in Japanese).

11) J. W. Ekin, F. R. Fickett and A. F. Clark : Adv. Cryo. Eng., 22 (1977).

12) K. Takahashi, S. Awaji, Y. Sasaki, K. Koyama and K. Watanabe : J. Cryo. Soc. Jpn., 41 (2006) (in Japanese).

2007 年 2 月 13 日受理, 2007 年 5 月 16 日採録 